\title{
Hubungan Antara Interaksi Sosial Teman Sebaya dengan Penerimaan Sosial Siswa Kelas XI
}

\section{Maria Winayang Andangjati1*, Tritjahjo Danny Soesilo², Yustinus Windrawanto ${ }^{3}$}

${ }^{123}$ Program studi Bimbingan dan Konseling, Universitas Kristen Satya Wacana, Salatiga, Indonesia *e-mail: mariawinayang87@gmail.com

\begin{abstract}
Abstrak
Masih banyak dijumpai remaja yang belum dapat menyesuaikan diri dengan baik di lingkungan sosialnya. Hal tersebut menjadi salah satu penyebab terjadinya penolakan remaja dari kelompok teman sebayanya. Penelitian ini bertujuan untuk menganalisis hubungan antara interaksi sosial teman sebaya dengan penerimaan sosisal siswa kelas XI. Penelitian ini merupakan penelitian kuantitatif dengan pendekatan korelasional yang bertujuan untuk membuktikan ada tidaknya hubungan antara variabel Interaksi Sosial dengan Penerimaan Sosial. Instrumen penelitian menggunakan kuesioner. Subjek yang diteliti sebanyak 52 orang. Pengujian hipotesis dalam penelitian ini menggunakan teknik uji korelasi Pearson Product Moment. Sebelum melakukan pengujian korelasi, perlu dilakukan pengujian asumsi terlebih dahulu dengan melakukan uji normalitas data menggunakan uji Kolmogorov-Smirnov, dan uji linearitas dengan uji ANOVA. Hasil penelitian menunjukkan nilai signifikansi sebesar 0.001. Dengan demikian, hipotesis dalam penelitian ini diterima, yaitu ada hubungan positif antara interaksi sosial teman sebaya dengan penerimaan sosial siswa. Hubungan positif pada hasil uji memiliki makna jika semakin tinggi interaksi sosial teman sebaya, maka akan semakin tinggi pula penerimaan sosial siswa dan sebaliknya. Implikasi penelitian ini memberika dampak pada interaksi sosial siswa yang semakin membaik.
\end{abstract}

Kata kunci: interaksi sosial, penerimaan sosial

\begin{abstract}
There are still many adolescents who have not been able to adapt well to their social environment. This is one of the causes of rejection by adolescents from their peer groups. This study aims to analyze the relationship between peer social interactions and social acceptance of class XI students. This research is a quantitative study with a correlational approach that aims to prove whether there is a relationship between Social Interaction and Social Acceptance. The research instrument used a questionnaire. Subjects studied were 52 people. Testing the hypothesis in this study using the Pearson Product Moment correlation test technique. Before testing the correlation, it is necessary to test the assumptions first by testing the normality of the data using the Kolmogorov-Smirnov test, and the linearity test using the ANOVA test. The results showed a significance value of 0.001 . Thus, the hypothesis in this study is accepted, that is, there is a positive relationship between peer social interactions and student social acceptance. The positive relationship on the test results means that if the higher the social interaction of peers, the higher the student's social acceptance and vice versa. The implication of this study has an impact on students' social interactions that are getting better.
\end{abstract}

Keywords: social interaction, social acceptance

\footnotetext{
${ }^{*}$ Corresponding author.

Received 30 Januari 2021; Accepted 1 Maret 2021; Available online 8 April 2021 (C) 2021 MI All Rights Reserved
} 


\section{Pendahuluan}

Masa remaja merupakan masa yang sangat penting dalam proses perkembangan. Perkembangan pada masa remaja seharusnya mendapatkan perhatian dari berbagai pihak, terutama dari lingkungan sosialnya (Albanjari, 2018; Mardjan, Prabandari, Hakimi, \& Marchira, 2018). Remaja dalam kehidupan sehari-hari berusaha mencari pengakuan atas keberadaannya di lingkungan sosialnya. Penerimaan keberadaan remaja dalam hubungan dengan teman sebayanya ataupun orang dewasa sangat berpengaruh pada kemampuan remaja dalam membina hubungan dengan orang lain. Remaja memiliki berbagai macam tugas perkembangan yang harus dilalui dalam perkembangan kehidupan sosialnya agar semua dapat berjalan dengan baik di masa yang akan datang. Salah satunya adalah membina hubungan sosial dengan teman sebaya dan orang dewasa selain guru dan orang tua (Nuryani \& Paramata, 2018; Winarsih \& Saragih, 2016). Remaja yang berhasil menjalankan tugas perkembangannya dengan baik akan mampu berinteraksi dengan teman sebayanya dan akan diterima dalam kelompok pertemanan.

Saat ini masih banyak dijumpai remaja yang belum dapat menyesuaikan diri dengan baik di lingkungan sosialnya. Hal tersebut menjadi salah satu penyebab terjadinya penolakan remaja dari kelompok teman sebayanya. Penolakan atau penerimaan pertemanan sebaya berpengaruh besar terhadap perkembangan sosial remaja (Malihah, 2014; Mirawati, 2015). Dalam hal ini, penerimaan teman sebaya akan berpengaruh pada kesempatan remaja untuk belajar berinteraksi, sedangkan penolakan akan menyebabkan ruang interaksi dan sosialisasi remaja menjadi sempit sehingga dapat menghambat perkembangan kepribadian remaja tersebut. Permasalahan sosial teman sebaya masih banyak ditemukan di sekolahsekolah, salah satunya adalah di SMA Virgo Fidelis Bawen. Berdasarkan wawancara awal dengan guru BK, diperoleh keterangan bahwa permasalahan penerimaan sosial dan interaksi sosial teman sebaya di sekolah tersebut cukup kompleks. Hal ini dikarenakan adanya keberagaman karakter, suku, dan budaya. Siswa siswi di SMA Virgo Fidelis Bawen tidak hanya berasal dari dalam kota, tetapi juga berasal dari luar kota dan luar pulau. Selanjutnya, diperoleh informasi lain bahwa di sekolah tersebut ada siswa yang berasrama dan non asrama. Hal ini menjadi penyebab utama isu penerimaan sosial di sekolah tersebut. Anak-anak diluar pulau Jawa kesulitan untuk bersosialisasi dengan anak yang lain sehingga mengakibatkan mereka kurang mampu berinteksi dan mengalami kesulitan dalam berbagai kegiatan di sekolah maupun sehari-hari.

Interaksi sosial teman sebaya adalah hubungan antara individu dalam suatu kelompok yang rata-rata anggota kelompoknya memiliki usia dan kematangan yang sama serta di dalamnya terdapat ketertarikan, perhatian, dan saling mempengaruhi satu sama lain (Hasti \& Nurfarhanah, 2013; Widyaningrum \& Sumarwoto, 2013). Saat remaja maka tingkat keakraban dengan teman sebaya sangat tinggi. Pemikiran remaja masih sangat labil dan mudah terpengaruh oleh lingkungan (Herfinaly \& Aryani, 2013; Sartika, 2013). Dalam mengambil keputusan masih banyak remaja yang terpengaruh oleh temennya tanpa mempertimbangkan hal tersebut. Dalam berinteraksi diperlukan sebuah penerimaan sosial. Penerimaan sosial adalah pengakuan, pemilihan, dan penghargaan terhadap individu baik oleh individu lain maupun kelompok sosial secara utuh sehingga individu merasa aman, nyaman, dan diakui keberadaanya (Dominika \& Virlia, 2018; Maiaweng, 2019). Penerimaan sosial diartikan sebagai diterima dan diakui individu di dalam suatu kelompok sosial.

Penelitian yang dilakukan oleh Lating (2016) menyatakan bahwa remaja mengalami hambatan dalam perkembangan interaksi sosial jika keterampilan berkomunikasi rendah. Penelitian yang dilakukan oleh Mariyam (2015) mengenai kemampuan interaksi sosial dengan peneriman teman sebaya, menunjukkan bahwa ada hubungan positif antara kemampun interaksi sosial dengan penerimaan teman sebaya pada siswa kelas VII. Berdasarkan hasil penelitian tersebut, tingkat keeratan korelasi antara interaksi sosial teman sebaya dengan penerimaan sosial berada pada kategori rendah atau lemah yaitu 0,31. Selanjutnya, penelitian serupa yang dilakukan oleh Yuliani, Syahriman, \& Sinthia (2019) menunjukkan bahwa terdapat hubungan yang positif dan signifikan antara interaksi sosial 
teman sebaya dengan penerimaan sosial pada siswa kelas XI. Dalam penelitian tersebut, tingkat keeratan korelasi antara interaksi sosial teman sebaya dengan penerimaan sosial masuk dalam kategori sangat kuat. Adapun penelitian lain oleh Sutarjo (2014) menunjukkan bahwa ada hubungan yang positif dan signifikan antara interaksi sosial teman sebaya dengan penerimaan sosial siswa. Sesuai dengan hasil uji penelitian tersebut diketahui bahwa sumbangan efektif variabel interaksi sosial teman sebaya terhadap variabel penerimaan sosial adalah sebesar $45,6 \%$.

Dapat dikatakan bahwa semakin tinggi tingkat interaksi sosial teman sebaya pada siswa, maka akan semakin tinggi pula tingkat penerimaan sosialnya, dan sebaliknya. Tujuan penelitian ini adalah untuk membuktikan ada tidaknya hubungan antara interaksi teman sebaya dengan penerimaan sosial siswa kelas X SMA Virgo Fidelis Bawen. Pada penelitian ini aspek penerimaan sosial yang diukur adalah Validation and Caring, Conflict and Betrayal, Companionship and Recreation, Help and Guidance, Intimate Exchange, Conflict Resolution. Aspek interaksi sosial teman sebaya yang diukur adalah jumlah waktu remaja dengan teman sebaya, keterlibatan remaja bermain dengan teman sebaya, kecenderungan bermain peran, berperan asosiatif, dan sikap kerjasama.

\section{Metode}

Penelitian ini merupakan penelitian korelasional yang bertujuan untuk mengetahui dan membuktikan sejauh mana keeratan hubungan antara variabel bebas dengan variabel terikat (Soesilo, 2018). Pendekatan yang digunakan adalah pendekatan kuantitatif dengan tujuan untuk menguji variabel bebas (independent) yaitu interaksi sosial teman sebaya dengan variabel terikat (dependent) yaitu penerimaan sosial. Dalam penelitian ini, subjek yang diteliti adalah iswa SMA Virgo Fidelis Ambarawa kelas $X$ yang berjumlah 52 siswa. Teknik sampling menggunakan teknik Probability Sampling (Total Sampling) dengan jumlah siswa sebanyak 52 siswa. Teknik total sampling digunakan karena jumlah populasi kurang dari 100 orang.

Pengumpulan data dalam penelitian ini dilakukan dengan menyebarkan angket berskala Likert. Skala pengukuran yang dipakai pada penelitian ini adalah skala interaksi sosial teman sebaya dan penerimaan sosial. Jenis skala pengukuran yang digunakan adalah skala Likert dengan pilihan jawaban yaitu Sangat Sesuai $(S S=$ skor 4$)$, Sesuai $(S=$ skor 3$)$, Kurang Sesuai $(K S=$ skor 2$)$, Tidak Sesuai $(T S=$ skor 1$)$. Empat pilihan jawaban tersebut bertujuan untuk menghindari jawaban netral atau ragu-ragu dari responden. Adapun pernyataan-pernyataan yang disusun didalam instrumen penelitian terdiri atas dua komponen aitem yaitu, favorable (pernyataan mendukung) dan unfavorable (pernyataan tidak mendukung). Angket yang digunakan dalam penelitian ini merupakan adopsi dari skripsi Sutarjo (2014).

Teknik analisis data dalam penelitian ini dilakukan dengan uji korelasi menggunakan teknik Pearson Product Moment untuk membuktikkan ada-tidaknya hubungan dan melihat besar-kecilnya hubungan antar variabel dalam penelitian. Sebelum melakukan pengujian korelasi, perlu dilakukan pengujian asumsi terlebih dahulu dengan melakukan uji normalitas data menggunakan uji Kolmogorov-Smirnov, dan uji linearitas dengan uji ANOVA.

\section{Hasil dan Pembahasan}

Berdasarkan hasil uji daya diskriminasi terhadap iitem-item pada skala Interaksi Sosial (X) yang telah dilakukan pada tahap pertama dan kedua diketahui bahwa ada 11 dari total 30 item yang memiliki nilai Corrected Item-Total Correlation kurang dari 0.30. Oleh karena itu, item-item tersebut harus digugurkan dan tidak dimasukkan dalam uji berikutnya. Setelah item tersebut dieliminasi, terdapat sisa sebanyak 19 aitem. Selanjutnya, dilakukan pengujian daya diskriminasi terhadap 19 item yang tersisa. Selanjutnya, dilakukan pengujian daya diskriminasi terhadap 19 item yang tersisa. Hasilnya, diketahui bahwa seluruh item pada skala Interaksi Sosial memiliki nilai Corrected Item-Total Correlation $>0.30$. Dengan 
demikian, item pada skala Interaksi Sosial dinyatakan valid, sehingga dapat digunakan dalam uji analisis ditahap berikutnya. Adapun total skor tertinggi dari 19 item tersebut adalah 73 dan total skor terendah adalah 26. Selanjutnya, hasil uji reliabilitas pada variabel Interaksi Sosial menunjukkan nilai Cronbach's Alpha lebih dari 0.700 yaitu 0.886 , sehingga dinyatakan reliabel.

Berdasarkan hasil pengujian daya diskriminasi item pada skala Penerimaan Sosial (Y) yang telah dilakukan pada putaran pertama diketahui bahwa ada 11 dari total 32 item yang memiliki nilai Corrected Item-Total Correlation kurang dari 0.30. Oleh karena itu, 11 item tersebut harus digugurkan dan tidak dimasukkan dalam uji berikutnya. Selanjutnya, dilakukan pengujian kembali terhadap 21 item sisanya. Berdasarkan hasil pengujian daya diskriminasi item putaran kedua, diketahui bahwa 21 item tersebut memiliki nilai Corrected Item-Total Correlation > 0.30. Dengan demikian, item-item pada skala Penerimaan Sosial dinyatakan valid, sehingga dapat digunakan untuk uji analisis pada tahap selanjutnya. Adapun total skor tertinggi dari 21 item tersebut adalah 84 dan total skor terendah adalah 33. Berdasarkan hasil uji reliabilitas pada variabel Penerimaan Sosial diketahui nilai Cronbach's Alpha lebih dari 0.700 yaitu 0.941 , sehingga dinyatakan reliabel. Sebelum dilakukan pengujian hipotesis, telebih dahulu dilakukan pengujian normalitas dan linearitas. Adapun hasil pengujian dapat dilihat secara lebih detail pada tabel berikut.

Tabel 2. Hasil Uji Normalitas dan Linearitas

\begin{tabular}{ccc}
\hline One-Sample Kolmogorov-Smirnov & Asymp. Sig. (2-tailed) & $\mathbf{0 , 2 0 0}$ \\
\hline ANOVA Table & Sig. Deviation from Linearity & 0,875 \\
\hline
\end{tabular}

Berdasarkan hasil uji normalitas dengan One-Sample Kolmogorov-Smirnov Test, diketahui nilai Sig. yaitu sebesar 0,200 >0,05; maka nilai residual dalam penelitian ini dinyatakan berdistribusi normal. Berikutnya, berdasarkan hasil pengujian linearitas dengan uji ANOVA, diketahaui nilai Sig. Deviation from Linearity yaitu 0,875 >0,05; maka dapat dikatakan terdapat hubungan yang linear antara variabel $X$ dengan $Y$. Dikarenakan hasil pengujian normalitas dan linearitas dalam penelitian ini telah memenuhi prasyarat, maka selanjutnya dilakukan uji hipotesis dengan teknik korelasi Pearson Product Moment. Hasil uji hipotesis dapat dilihat pada tabel berikut:

Tabel 3. Hasil Uji Korelasi

\begin{tabular}{ccc}
\hline & Correlations & \\
\hline Variabel & Pearson Correlation & Sig. (1-tailed) \\
\hline Interaksi Sosial $(\mathrm{X})$ & 0.426 & 0.001 \\
Penerimaan Sosial $(\mathrm{Y})$ & & \\
\hline
\end{tabular}

Dasar pengambilan keputusan yang digunakan pada pengujian hipotesis dalam penelitian ini menyatakan bahwa jika nilai signifikansi $<0.05$, maka terdapat korelasi antara variabel bebas dan variabel terikat. Data pada tabel menunjukkan nilai signifikansi yaitu sebesar $0.001<0.05$ dengan nilai Pearson Correlation positif yaitu 0.426 . Dengan demikian, hipotesis dalam penelitian ini diterima, yaitu ada hubungan positif antara interaksi sosial teman sebaya dengan penerimaan sosial siswa. Hubungan positif pada hasil uji memiliki makna jika semakin tinggi interaksi sosial teman sebaya, maka akan semakin tinggi pula penerimaan sosial siswa dan sebaliknya.

Berikutnya, nilai Pearson Correlation pada hasil uji hipotesis dalam penelitian ini adalah sebesar 0.426 . Maka, mengacu pada pedoman derajat keeratan korelasi sesuai dengan tabel klasifikasi nilai koefisien korelasi $r$ Pearson, hasil penelitian ini menunjukkan bahwa korelasi antara variabel Interaksi Sosial (X) dan Penerimaan Sosial (Y) ada pada derajat korelasi sedang. Hasil penelitian ini menunjukkan bahwa korelasi antara variabel interaksi sosial dengan variabel penerimaan sosial adalah positif dengan tingkat korelasi 
sedang. Korelasi yang positif memiliki makna bahwa apabila semakin tinggi interaksi sosial siswa, maka akan semakin tinggi pula penerimaan sosialnya. Temuan ini sejalan dengan hasil penelitian yang dilakukan oleh Sutarjo (2014); Mariyam (2015); Yuliani et al., (2019) yang menujukkan adanya hubungan positif antara interaksi sosial dengan penerimaan sosial subjek masing-masing penelitian. Temuan-temuan tersebut semakin memperkuat bukti bahwa penerimaan sosial individu terhadap individu lain didalam kelompoknya dipengaruhi oleh variabel interaksi sosial.

Dalam hal ini, dapat dikatakan bahwa seorang individu akan cenderung menerima atau menolak keberadaan seseorang dalam lingkungannya apabila terdapat suatu interaksi didalamnya (Riansyah \& Wulandari, 2017; Siregar, 2017). Sebagai contoh yaitu seorang remaja yang memiliki lebih banyak waktu untuk dihabiskan dengan teman sebaya dalam satu kelompoknya, secara tidak sengaja akan membentuk ikatan dengan orang-orang dalam kelompok tersebut. Selanjutnya, mereka akan cenderung melakukan aktivitas atau kegiatan yang sama. Dengan demikian, terjadilah interaksi yang intens diantara mereka. Hal inilah yang kemudian akan memicu timbulnya perasaan terhadap sesama teman sebaya didalam komunitas atau kelompoknya. Hal ini mencakup terbentuknya sikap toleran, bekerja sama, dan saling membantu. Pada saat terjadi interaksi yang demikian, maka akan terbuka peluang terjadinya penolakan atau penerimaan sosial didalam kelompok (Maiaweng, 2019; Soraya \& Jannah, 2011). Sebaliknya, jika seorang individu jarang atau bahkan tidak memiliki waktu untuk dihabiskan bersama dengan teman sebaya dalam kelompoknya, maka bonding atau ikatan yang terjalin antara individu tersebut dengan kelompoknya akan rendah. Dengan demikian, maka tingkat penerimaan sosialnya akan semakin kecil. Akan tetapi, sekalipun jumlah waktu yang dihabiskan seorang individu dengan temannya intens, hal ini tersebut tidak selalu menjamin bahwa akan terjadi penerimaan sosial dalam kelompok teman sebaya.

Hal ini disebabkan oleh kecocokan antar individu dalam suatu kelompok pertemanan. Dalam satu kelompok pertemanan terdapat sejumlah individu dengan sifat yang berbedabeda yang tentu berpengaruh pada cocoktidaknya seseorang untuk terus berteman. Salah satu faktor yang mendasari seseorang diterima oleh orang lain yaitu faktor sugesti yang mencakup suatu proses dimana individu menerima suatu cara penglihatan atau pedomanpedoman tingkah laku dari orang lain serta pandangan atau sikap dari dirinya yang kemudian diterima oleh orang lain (Satya, 2016; Wahyuni, 2014). Pada praktiknya, didalam sebuah kelompok teman sebaya akan selalu ada peran dan pengaruh teman, adanya peraturan tidak tertulis yang terbentuk dengan sendirinya, serta perbedaan kemampuan setiap individu untuk menyesuaikan diri dalam kelompok (Gurnita \& Suwarti, 2013; Hariz, 2011). Seorang individu akan selalu memilliki pandangan dan sikap setuju dan tidak setuju terhadap sebuah peraturan tidak tertulis yang terbentuk didalam kelompoknya serta sikap dan sifat individu lain didalamnya.

Lebih lanjut, tidak setiap individu mampu memberikan kesan baik atau pandai membawa diri serta melakukan penyesuaian diri sehingga mampu masuk dalam sebuah kelompok pertemanan. Hal ini sesuai dengan penjelasan Hurlock (2002) yang menyatakan bahwa salah satu faktor yang menyebabkan remaja diterima atau ditolak oleh teman sebaya adalah penampilan (performance) dan perbuatan meliputi rupa menyenangkan atau paling tidak rapi, cekatan dalam bekerja, mahir bergaul, dan aktif dalam kegiatan-kegiatan kelompok. Hal-hal tersebut tentu diperlukan oleh individu dalam upaya menyesuaikan diri dan memberikan kesan yang baik dari dirinya agar mendapatkan penerimaan sosial oleh kelompok pertemanan yang dikehendakinya. Dengan demikian, hasil temuan dalam penelitian ini memberikan makna bahwa interaksi sosial teman sebaya yang mencakup intensitas berinteraksi, peran teman, keterlibatan dalam kelompok dan sikap individu memiliki peran dalam menentukan penerimaan sosial seseorang terhadap individu lain kedalam sebuah kelompok pertemanan. 


\section{Simpulan}

Berdasarkan hasil penelitian terdapat hubungan antara variabel interaksi sosial dengan penerimaan sosial. Dalam penelitian ini disimpulkan bahwa terdapat hubungan antara variabel Interaksi Sosial dengan Penerimaan Sosial. Hubungan yang terjadi antara variabel Interaksi Sosial dengan Penerimaan Sosial memiliki nilai positif.

\section{Daftar Pustaka}

Albanjari, E. S. (2018). Mengatasi Kenakalan Remaja Pada Masa Transisi. Tadrib: Jurnal Pendidikan Agama Islam, 4(2). https://doi.org/https://doi.org/10.19109/tadrib.v4i2.2450

Dominika, \& Virlia, S. (2018). Hubungan Kepribadian Ekstrovert-introvert dan Penerimaan Sosial terhadap Siswa Difabel pada Siswa. Konselor, 5(1). https://doi.org/https://doi.org/10.24036/02018718735-0-00

Gurnita, W. N., \& Suwarti, S. (2013). Studi Deskriptif Kuantitatif Tentang Pola Kelekatan Remaja Dengan Teman Sebaya Pada Peserta Didik Di Sltp Negeri 1 Ayah, Kebumen. Psycho Idea, 11(2). https://doi.org/https://doi.org/10.30595/psychoidea.v11i2.511

Hariz, S. A. (2011). Hubungan Antara Persepsi Keharmonisan Keluarga dan Konformitas Teman Sebaya Dengan Kenakalan Remaja. Persona, 2(1). https://doi.org/https://doi.org/10.30996/persona.v2i1.57

Hasti, R., \& Nurfarhanah. (2013). Hubungan Antara Interaksi Sosial Teman Sebaya Dengan Kemandirian Perilaku Remaja ( Studi Korelasional Terhadap Smp N 1 Padang Panjang ). Konselor, 2(1). https://doi.org/https://doi.org/10.24036/02013211267-0-00

Herfinaly, R., \& Aryani, L. (2013). Interaksi Sosial Remaja Yang Bersekolah di Homeschooling Dengan Menggunakan Metode Distance Learning. Jurnal Psikologi, 9(1). https://doi.org/http://dx.doi.org/10.24014/jp.v9i1.147

Hurlock, E. B. (2002). Psikologi Perkembangan: Suatu Pendekatan Sepanjang Rentang Kehidupan. Jakarta: Penerbit Erlangga.

Lating, A. D. (2016). Konflik Sosial Remaja Akhir (Studi Psikologi Perkembangan Masyarakat Negeri Mamala Dan Morella Kecamatan Leihitu Kabupaten Maluku Tengah. ALILTIZAM, 1(2). https://doi.org/https://doi.org/10.33477/alt.v1i2.204

Maiaweng, P. C. D. (2019). Korelasi Harga Diri Dan Penerimaan Sosial Terhadap Kepribadian Yang Sehat pada Mahasiswa STT Jaffray Makassar. Jurnal Jaffay, 1. https://doi.org/http://dx.doi.org/10.25278/jj71.v9i1.86

Malihah, E. (2014). Kenakalan Remaja Akibat Kelompok Pertemanan Siswa. Forum IImu Sosial, 41(1). https://doi.org/https://doi.org/10.15294/fis.v4111.5373

Mardjan, M., Prabandari, Y. S., Hakimi, M., \& Marchira, C. R. (2018). Emotional Freedom Techniques for Reducing Anxiety and Cortisol Level in Pregnant Adolescent Primiparous. UNNES Journal of Public Health, 7(1). https://doi.org/https://doi.org/10.15294/ujph.v7i1.19212

Mariyam, S. (2015). Hubungan Antara Kemampuan Interaksi Sosial Dengan Penerimaan Teman Sebaya Pada Siswa Kelas VII Di MTs.Nyai H Ashfiyah Surabaya. Universitas Islam Negeri Sunan Ampel.

Mirawati, I. (2015). Media Konsultasi Online Sebagai Alternatif Upaya Penanganan Masalah Remaja. EDULIB: Journal Of Library And Information Science, 5(1). https://doi.org/https://doi.org/10.17509/edulib.v5i1.2306 
Nuryani, N., \& Paramata, Y. (2018). Intervensi Pendidik Sebaya Meningkatkan Pengetahuan, Sikap, dan Perilaku Gizi Seimbang pada Remaja di MTsN Model Limboto. Indonesian Journal Of Human Nutrition, https://doi.org/https://doi.org/10.21776/ub.ijhn.2018.005.02.4

Riansyah, H., \& Wulandari, W. (2017). Layanan bimbingan kelompok dalam meningkatkan interaksi sosial siswa. Teraputik: Jurnal Bimbingan Dan Konseling, 1(1). https://doi.org/https://doi.org/10.26539/1110

Sartika, W. (2013). Masalah-Masalah Interaksi Sosial Siswa Dengan Teman Sebaya Di Sekolah. Konselor, 2(1). https://doi.org/https://doi.org/10.24036/0201321877-0-00

Satya, M. S. (2016). Strategi Masyarakat Etnis Tionghoa Dan Melayu Bangka Dalam Membangun Interaksi Sosial Untuk Memperkuat Kesatuan Bangsa. Jurnal Pendidikan IImu Sosial, 25(1). https://doi.org/https://doi.org/10.17509/jpis.v25i1.3667

Siregar, R. Y. (2017). Meningkatkan Interaksi Sosial Siswa Melalui Layanan Bimbingan Kelompok Teknik Role Playing Pada Siswa Kelas Viii Smp Negeri 1 Perbaungan T.A 2015/2016. JURNAL https://doi.org/https://doi.org/10.31289/diversita.v2i2.269

DIVERSITA

2(2).

Soesilo, T. D. (2018). Penelitian Inferensial dalam Bidang Pendidikan. Salatiga: Satya Wacana University Press.

Soraya, R., \& Jannah, S. R. (2011). Hubungan Antara Penerimaan Sosial Kelompok Kelas dengan Kepercayaan Diri pada Siswa Kelas I SLTP XXX Jakarta. Jurnal Kependidikan Triadik, 14(1).

Sutarjo, D. A. P. (2014). Hubungan antara Interaksi Sosial Teman Sebaya dengan Penerimaan Sosial pada Siswa Kelas X SMA Negeri 9 Yogyakarta. Universitas Negeri Yogyakarta.

Wahyuni, S. (2014). Efektivitas Program Resolusi Konflik Untuk Meningkatkan Kemampuan Pemecahan Masalah Sosial Siswa Yang Terlibat Perilaku Bullying. Jurnal Psikologi, 10(1). https://doi.org/http://dx.doi.org/10.24014/jp.v10i1.1179

Widyaningrum, Y., \& Sumarwoto, V. D. (2013). Pengaruh Bimbingan Pribadi-Sosial Dengan Pendekatan Rational Emotive Therapy Untuk Meningkatkan Interaksi Sosial Dengan Teman Sebaya. Counsellia: Jurnal Bimbingan Dan Konseling, 2(3). https://doi.org/http://doi.org/10.25273/counsellia.v3i2.251

Winarsih, \& Saragih, S. (2016). Keharmonisan Keluarga, Konformitas Teman Sebaya dan Kenakalan Remaja.

Persona,

$5(1)$. https://doi.org/https://doi.org/10.30996/persona.v5i01.743

Yuliani, M. T., Syahriman, S., \& Sinthia, R. (2019). Yuliani, M. T., Syahriman, \& Sinthia, R. ). Hubungan Antara Interaksi Sosial Teman Sebaya Denagn Penerimaan Sosial Siswa Kelas XI IPA SMA Negeri 09 Kota Bengkulu. Jurnal IImiah BK, 2(3). https://doi.org/https://doi.org/10.33369/consilia.2.3.245-253 